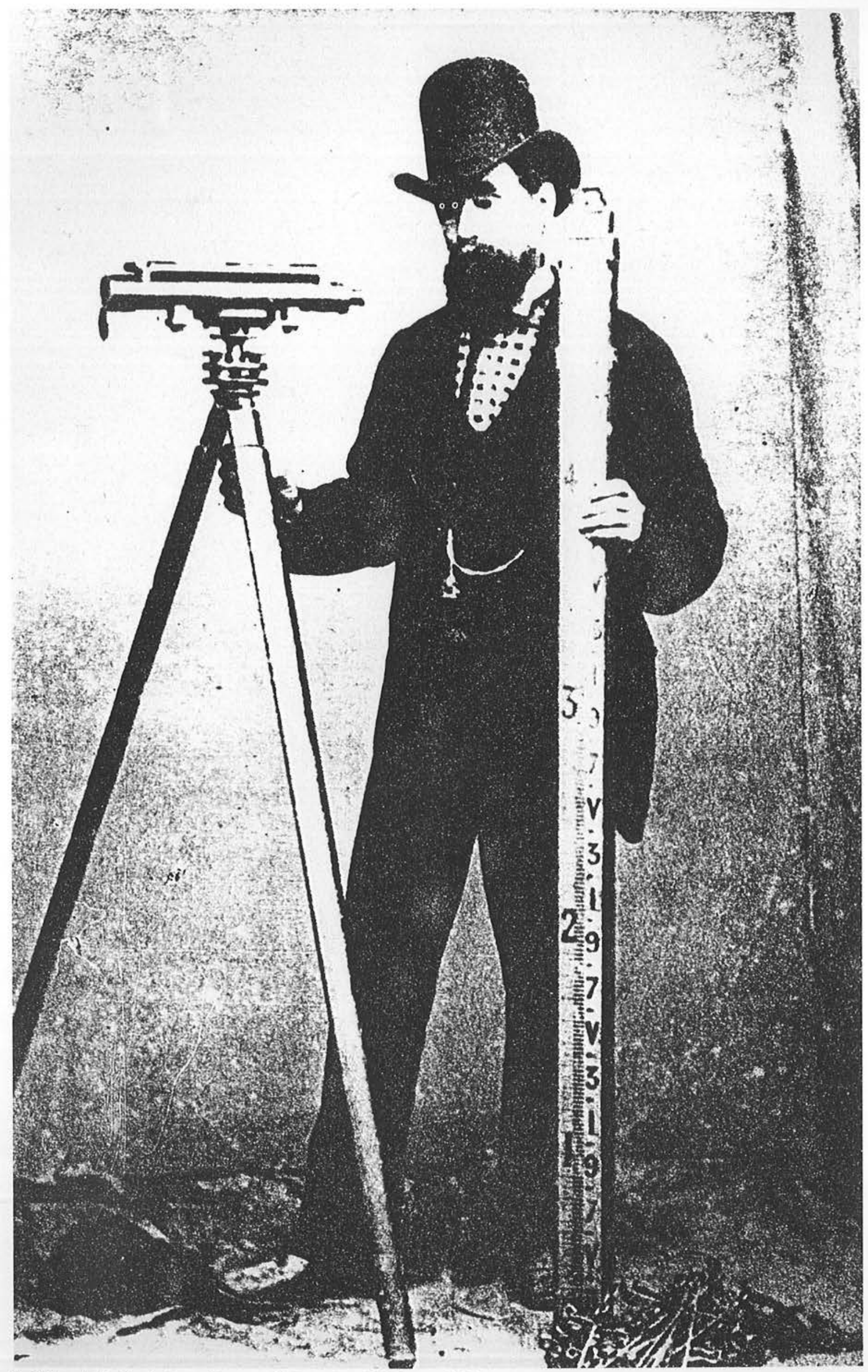

fig 1 (above) Mr Charles Davy, Surveyor [23 December 1843], Taranaki Museum 
GISELLE BYRNES

Between the Lines:

\section{Expressing the Particular in the Discourse of Surveying}

"There is something exhilarating in daily coming on new country, and descrying new objects of interest." (John Turnbull Thomson, Chief Surveyor of Otago, 1857)

\section{Introduction}

"The first impression of a place," wrote the surveyor Edwin Brookes of his arrival in Taranaki in 1874, "[is] generally the most lasting, and on my first glimpse of New Plymouth I formed an opinion that I never modified afterwards." ${ }^{1}$ To the nineteenth-century European settler - or unsettler - land that lay uncultivated was unproductive. British emigrants expected that the transformation of the New Zealand landscape would 'civilise' what appeared to be a wild and unlettered land. This part of the new world was to be a 'Britain of the South"; an antipodean outpost of empire that replicated, then reproduced the values, attitudes and aspirations of the old. The task of the colonial surveyor, as Mary Louise Pratt has observed of the colonial explorer, "was to incorporate a particular reality into a series of interlocking information orders - aesthetic, geographical, mineralogical, botanical, agricultural, economic, ecological, ethnographical and so on... In scanning prospects in the spatial sense... [the explorers'] eye knows itself to be looking at the prospects in a temporal sense - as possibilities for the future, resources to be developed, landscapes to be peopled, or re-peopled by Europeans." 2 Within the matrix of colonialism, surveying was the active universalization of a habitable and productive space; in providing capitalism with new geopolitical territory, surveying was implicated in a dialectic of technological innovation and representation. ${ }^{3}$ "It was not by discovering novelties," Paul Carter has argued, "but by ordering them, rendering them conceptually and culturally visible, that the great work of colonization went ahead. In a sense, it was the process of surveying itself that constituted the decisive discovery, rather than the fruits of exploration. It was the method of giving objects great and small a place in the world, the picturesque logic of connection and constrast, that ensured they could never be lost again or overlooked." 4

This paper will focus on the discourse of surveying as a site where the tension between the universal and the particular was played out in a specifically colonial context. This tension was manifest in the fissure between objectivity and subjectivity; between subjective experience and the need to structure that experience in terms of absolutes, to transform it into a productive space. It is suggested here that the act of land surveying was a mimetic act which expressed both particularity and universality. Surveying was (and is) predicated on the specific and the accurate; lines, boundaries and discrete measurements dictate the need to quantify, categorise and control. As Brad Patterson has recently argued, "'spatial goals'... translated into landscape form, constitute the cutting edge at which actual cadastral engraving commences, for it is at this point that the precise layouts of farm boundaries, paddocks, fences, roads, villages and townships are determined." 5 Surveying the land, however, involved more than attention to detail in effecting a physical transformation of cultural space. The inscription and description of landscape also demanded participation in universalising conventions; reading the land invoked conventions of the panoptic and the picturesque, while the strategies of naming and mapping were employed in writing the land. Moreover, it is suggested here that these tensions were embodied in the generic persona of the surveyor, whose subjectivity was a site of constant negotiation between particularity and the universal conventions which gave such detail meaning. (fig 1) 
As a master narrative of crisis, postcolonial discourse itself has a propensity to universalize; to subsume difference rather than celebrate it, tending toward a transcendent theorizer which is assumed to be outside time, space and power relations. It has also been questioned why the homogenization of postmodern de-centring theories should emerge at a time when various minortity groups are asserting their claims to political and cultural identity. ${ }^{6}$ Critical enquiry, as a latter-day visitation to the past, often risks re-inscribing the very colonial discourses it seeks to deconstruct. As the objects of the historian's enquiry, colonial texts are again privileged; they are once more accorded the space (and the audience) they sought in their initial production. Colonial discourse analysis then, "walks a thin line between the reconfirmation of and the flight from the known," and the study of colonial discourse has largely been a study of this tension. The problem facing critics, as Robert Young points out, is "whether... to locate evidence of historical examples of resistance, as is often assumed, or whether the analysis of colonial discourse can itself make political interventions in terms of current understanding and analysis." ${ }^{8}$ An analysis of colonial discourses must, therefore, address the strategies and tactics by which these discourses claimed, and were accorded legitimacy at a specific moment; but must seek to do so without repeating those same moments.

As an alternative critical strategy, the 'place' or 'text' may be defined as both a product of the expectations previously held by the observer - the travellers' interpretation or appreciation of place was often what they expected to find - and of the dialogue between coloniser and colonised. This kind of methodology replaces the apparant uniformity of colonialism with the recognition of a diversity of discourses, where the distribution of power is more interactive than passive. The surveyor's response to the 'new' environment was then, fashioned as much by his interaction with local Maori as it was determined by his own cultural pre-conditioning. This is not dissimilar to Bernard Smith's argument where [in imagining the Pacific], "Europeans imagined from a reality that they had to come to terms with, not a fancy or a fantasy that might eventually disappear." ${ }^{\prime 9}$ As Carter has also proposed, the place did not precede the traveller; it was the offspring of his intention.(Carter, p. 349) These introductory comments are significant here because the shortcomings of the discursive system they describe are evident in surveying narratives and the accompanying maps; texts which appear to be homogenous controlling devices, but are themselves split both between and within differential discourses.

"The particular," Theodor Adorno argued in Negative Dialectics, "would not be definable without the universal that identifies it, according to current logic; but neither is it identical to the universal." 10 Particularity and universality, while different, are interdependent. Adorno, however, maintained that " $[t]$ he concept of the particular is always its negation at the same time; it cuts short what the particular is and what nonetheless cannot be directly named, and it replaces this with identity. This negative, wrong, and yet simultaneously necessary moment is the stage of dialectics."(Adorno, p. 173) Hegel made it clear that the negation of space was to be found in the point; that the difference of space is "the negation of space itself, because this is immediate differenceless self-externality, the point." ${ }^{11}$ As Derrida has argued, the Western philosophical tradition rests on hierarchical binary oppositions which include unity/diversity, identity/difference and universality/specificity. These terms are interdependent, with the primacy of the first derivative from the second. 12 Or, as Elizabeth Gross has argued, "the primary or dominant term derives its privilege from a curtailment or suppression of its opposite." 13 This is not dissimilar to the French critic Lucien Goldmann's use of the term 'totality'; "the idea that the phenomenon can be comprehended only by first inserting it on the broader structure of which it is a part and in which it has a function." 14 Space thus accomodates a constant dialectic between the universal and the particular, and this particularity is dependent on exposing internal conflicts, contradictory logic, or totalization that requires supplemention.

Surveying is a spatial activity: spatiality is a concept which allows subjectivity to be understood as as a social representation. For the historian Michel de Certeau, "space is a practiced place"15; while, for Foucault, "space is fundamental in any form of communal life; space is fundamental in any form of power." 16 The space of the colony, with its semblance of homogeneity, included a multiplicity of fragmented spaces. "Colonial space," as J. K. Noyes has recently argued, 
"is not a universal space, but a space which has been produced. As such, it can be grasped as a historically specific organization of multiplicities into an apparent unity. The capitalist production of space relies upon the conjunction and collation of various diverse spaces... In short, capitalism not only produces a space in which it may perpetuate itself, but one in which subjectivity has meaning."(Noyes, p. 98) Deleuze and Guattari have also exposed how, within the capitalist system, colonization continually produces spaces, creating space out of a multiplicity of abstract qualities. ${ }^{17}$ The codification of colonial space also universalised that space; while facilitating movement through the coordination and control of activities, it simultaneously removed the particular meaning of space and time from much of ordinary experience.

Surveyors often searched for boundless and empty spaces. The Nelson surveyors Thomas Brunner and Samuel Stephens had both looked for the 'great plains' of the southern west coast on separate occasions. ${ }^{18}$ Cass, Torlesse and later Baker were among those who sought the plains of promise in Canterbury. Empty space is an already inscribed space, where paradoxically, "the things to be contained are not present."(Sack, p. 33) The attempt to visualise space in the absence of boundaries is also a fundamental component of colonizing vision. As Homi Bhabha has argued, "at the center of the originary myth of colonialist power... is the demand that the space it occupies be unbounded, its reality coincident with the emergence of an imperialist narrative and history, its discoures nondialogic, its enunciation unitary, unmarked by the trace of difference. ${ }^{19}$ When the space of the Other is generalised and universalised, it begins to lose meaning.

Within this colonial and mimetic space, however, slippages occured. These slippages between the ideal and the real find a parallel in the ambivalent identity of the colonial, which, as Homi Bhabha has suggested, is characteristic of colonial discourse in general. ${ }^{20}$ The intended plans for survey often could not be simply translated from script to soil. Indeed, the implementation of the plan was exercised tactically, surveyors frequently having to negotiate with an unsympathetic landscape and less than co-operative Maori. Maori opposition to surveying and surveyors was not uncommon. As early as July 1843, the Resident Agent in New Plymouth, Wicksteed, wrote to Colonel Wakefield:

I have had some trouble with Maori ... at the Waitara. A number of men belonging to Kapiti appeared lately among the Waitara people, and in conjunction with a chief, who lives some miles up the river, stopped a party of surveying men who were cutting a line preparatory to making a road. They were not armed and used no violence, but sat down in the road to the number of about 188, including men women and children, and quietly declared that they would not allow the white men to occupy any land at the Waitara. When the assistant surveyor and some of the white settlers attempted to reason with them they said "You are all Wicksteed's slaves, and we will not listen to you." As soon as I heard of this occurrence I withdrew all the Company's men from the Waitara, wishing at present to avoid collision with the natives. ${ }^{21}$

Under the instructions of Wi Kingi te Rangitake women had pulled up the survey pegs at Waitara in February 1860, and on the surveys south of the Waingongoro river in 1866-67.22 Edwin Brookes wrote of Te Whiti "forcibly turning off the ground the staff of surveyors then engaged upon the this work and carting all their equipment off the plains."(Brookes, p. 37) In Taranaki, the surveyor W. H. Skinner "... did about $21 / 2$ miles when to my surprise I found the pegs had been pulled out by the Hauhaus and I was obliged to search for the places again in order to continue my levelling, which impeded us very much \& I was unable to complete my work this evening." 23 While laying out military settlements in Taranaki in 1865-66, Percy Smith often had to work under the protection of covering parties. ${ }^{24}$ (fig 2)

\section{The Colonial Surveyor and Personal Particularity}

The task of the nineteenth-century surveyor was to define spaces of objectivity and subjectivity; to negotiate the specific and the general in the fragmented and hierarchically organized space within which he moved. If, as Hegel suggested, the negation of space is to be found in the point, then the subjectivity of the surveyor was located at this site. As Noyes suggests, the narrative of the traveller is the site of this tension: "[ $\mathrm{t}]$ his is because the conflicting tendency of subjective 


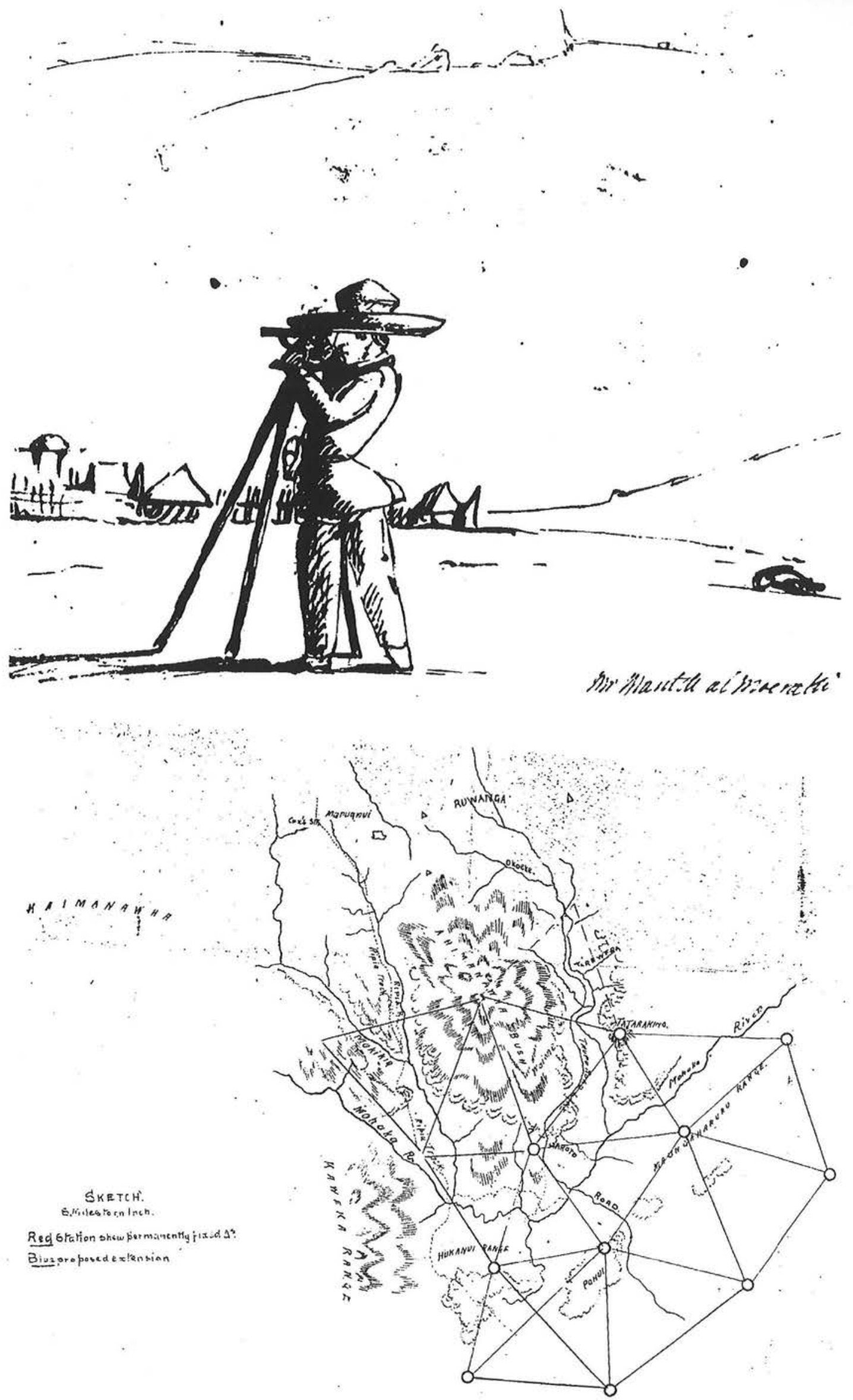

fig 2 (top) Francis Edward Nairn, Mr Mantell at Moeraki [1848], E333/84, Alexander Turnbull Library

fig 3 (bottom) Stephenson Percy Smith, FB37, Department of Survey and Land Information, Hamilton. This sketch from Smith's field book clearly illustrates how triangles informed the surveyor's vision of the land. 
experience toward self-fulfillment in looking on the one hand, and self-preservation in writing on the other hand is also a conflict between the need to structure ambient space in absolute terms, as homogeneous and borderless, and to render it knowable through the production of discrete spaces within well defined boundaries."(Noyes, p. 166)

It is suggested here that the surveyor - to universalise the persona - read the land and formulated the landscape, from an in-between place. This space between may be seen as a mimetic one, which Michael Taussig has recently argued for as "a space permeated by the colonial tension of mimesis and alterity, in which it is far from easy to say who is the imitator and who is the imitated, which is copy and which is original." 25 This was a contestatory site that demanded constant negotiation and compromise, and was, in Michel de Certeau's terms, a 'tactical' terrain. de Certeau defines a 'strategy' as "the calculus of force-relationships which becomes possible when a subject of will and power (a proprietor, an enterprise, a city, a scientific institution) can be isolated from an 'environment'... . It postulates a place that can be delimited as its own and serve as the base from which relations with an exterior... can be managed."(de Certeau, pp. 36-7). On the other hand, a 'tactic' is, for de Certeau, "a calculus which cannot count on a 'proper' (a spatial or institutional localization), nor thus on a border-line distinguishing the other as a visible totality ... [it is] a calculated action determined by the absence of a proper locus... it must play on and with a terrain imposed on it and organised by the law of a foreign power."(de Certeau, p. 37) This was a fluid space which shifted according to discursive context and content. Surveyors were travellers who brought their cultural baggage to bear on the environment they encountered. Their expectations in tact, they saw what they wanted to see in the new place. But their reading of it was modified by what they did not expect to find; a place and a people that were both exotic and familiar. The need to universalise was therefore predicated on the need to control. (fig 3)

Surveyors had an eye for the particular and often engaged in a fascination with detail. While surveying the Nelson hinterland, the surveyor Samuel Stephens paused to notice:

In the open parts of the country we had passed through, the ground was covered with a shrub, which I believe I have before described and called the satin plant, from the resemblance the under part of the leaf, when the skin or epidermis is removed from it, bears to that substance. Its colour is a very delicate straw or lemon colour, and from its being very elastic, properly speaking it may be said to resemble soft kid leather in its texture. I have little doubt ultimately, this substance may be applied to some profitable purpose in manufactures. The plant bears a very handsome blossom about the size of a crown piece, of a white colour with a yellow eye, something like the chrysanthiumum in form. The rain abating a little towards the evening, I sallied forth to take a view of the lake and surrounding country, which, although viewing it under very disadvantageous circumstances, was exceedingly interesting and beautiful. (Stephens, MS Papers 2698-1A)

Despite such frequent diversions, the surveyor had to conform to convention and the master narrative of the discourse, when confronted with the task of submitting a report or furnishing a map and translating his work into a medium for further dissemination. There was a constant tension between the joy of looking for its own sake, and the need to commit this gaze to print. This was, however, a productive tension. As the critic Edward Said has noted, "knowledge means rising above immediacy, beyond self, into the foreign and distant. The object of such knowledge is inherently vulnerable to scrutiny; this object is a 'fact' which, if it develops, changes, or otherwise transforms itself in the way that civilizations frequently do, nevertheless is fundamentally, even ontologically stable. To have knowledge of such a thing is to dominate it, to have authority over it." 26 Indeed, the eye acts as an instrument of mediation between the universal and the particular. But the eye does not merely gather information; it processes it to be subsumed within a larger epistemological scheme. Said explores the primacy of individual agency in his work Orientalism (1978), where he proposes close textual readings "to reveal the dialectic between individual text or writer and the complex collective formation to which his [sic] work is a contribution."(Said, p. 24) However, Said's opposition of particular and universal, individual consciousness versus totalization, and the unresolved contradiction in his critique of historicism and the political effects of its Eurocentric universalism, is, as Young suggests, "where the rejection of totalizing systems for particularism appeared to risk substituting a total fragmentation for total synthesis."(Young, p. 135) 
To universalise then, is to raise to a level of abstration where difference is negated and where power is exercised strategically. Conversely, to particularise is to recognise difference, and so to negotiate power in a tactical mode. Universalising employed the use of stereotype and category; to recognise the particular is to render the object visible. Moreover, in the transition from general to specific (and universal to particular) there occurs a shift in power. For example, when the surveyor Thomas Brunner ceases to see his Maori guide as a generic "native attendant" and comes to appreciate Kehu as an individual, the power relationship between the two alters; Brunner can only navigate a route down the West Coast of the South Island with Kehu's assistance and constant negotiation. ${ }^{27}$

The colonial surveyor's image of the landscape was determined as much by the universal (capitalist) demand for land as it was controlled by the sights of his particular 'cultural theodolite.' The surveyor saw his task as preparing the path for orderly colonization. He was the means of transforming the dynamic space of travelling into the fixed and passive space of settlement, viewing the country he passed through as if with the eyes of the future.(Carter, p. 20) Bernard Smith has already shown how Europeans in a 'new land' imposed their cultural expectations on the environment, and remodelled the landscape accordingly. ${ }^{28}$ Surveyors were instructed "to locate objects of cultural signficance: rivers, mountains, meadows, plains of promise... They were expected to arrest the country, to concentrate it into reversible roads which would summarize its content; they were expected to translate its extension into objects of commerce."(Carter, p. 56) "There is no doubt," wrote Felton Mathew to Hobson of his exploration of the Waikato region in the 1840s, [that] "it must become the great granary of the colony." 29 In 1841 the chief sureyor of the New Plymouth settlement, F. A. Carrington described New Zealand as "the Great Granary from its possessing such an immense extent of Land fit for Agriculture..." 30 "The valleys are particularly rich," wrote the Taranaki surveyor Thomas Kingwell Skinner in 1872, "and this is the best land you can find."(Skinner, p. 29)

Although their allegiance to the universal agenda of the colonial project cannot be underestimated, colonial surveyors were also inspired by the particulars of personal motivation. The desire to join the vanguard of exploratory expeditions into the new wilderness was a temptation few adventurous young colonists could resist. In his field book, the surveyor Charles Douglas wrote of:

the impulse which drove the bravest and best of Old Rome to face death and danger on the banks of the Danube or the Sandy Desart [sic] of Afraca [sic] and Asia impells the Briton to do likewise and plant his flag all over the World indifferent as to whether the danger to be faced is from prowling Savage, Feversmitten Jungles or Artic Snows... The impulse drove me out into the World, but the desire to then settle must have been omitted in my moral character, as here I am crouched under a few yards of calico with the rain pouring and the wind and the Thunder crashing down the Gorges of the mountains, a homeless, friendless Vagabond, with a past that has little to show of work done, and a future equally dreary, still I have never regretted adopting the life I am leading and can see that even if I and thousands more besides me fail in the life they are leading and die miserably the impulse which impells them to the search for knowledge about the unknown is for the benefit of mankind, and cheaply bought at any price. $^{31}$

Douglas' admission further illustrates how personality was itself a particular constructed in the process of travelling. As Paul Carter has observed, "the personality of travellers is not something there from the beginning, a quotient of inheritance and environment: it is an identity consciously constructed through travelling (Carter, p. 100). In The Road to Botany Bay, Carter argues that the diary was an intentional, self-referential and active transformation of space, in that the diarist used language to create both the space and the occasion in which to write. ${ }^{32}$

\section{Reading Particulars}

Reading, as the act of viewing with a conditioned eye, was central to the creation of colonial space, for reading articulated the unknown in terms of the known, and incorporated the 
preconceived spatial goals of transformation into the particular and immediate line of vision. Visual impressions played a primary role in the aquisition and management of colonial space "It is remarkable," wrote the Taranaki surveyor Edwin Brookes in the 1870s, "how attached a surveyor becomes to his theodolite. So it was with myself. My little star gazer, as I used to call it, went through the whole campaign with me. So jealous was I of it that it was never entrusted to other hands but once."(Brookes, p. 2) Reading integrated the viewer into the scene, willed him/her into the frame, to occupy and become a part of the space, fixing it in time and place. The nineteenthcentury observer, like the twentieth-century historian, re-invented this space every time it was observed. Fixed in texts, captured on the page, map or canvas, landscape, like history, was and is created at specific moments.

Surveyors read landscape with reference to the panoptic and the picturesque. The panoptic was both particular and universal; both subjective and conventional. Constructed from the first person, the ' $\mathrm{I}$ ' / eye, the panoptic perspective was, as Pratt has suggested, "unheroic, unparticularized, without ego, interest, or desire of its own... able to do nothing but gaze from a periphery of its own creation, like the self-effaced, non-interventionist eye that scans the Other's body."(Pratt, p. 143) The panoptic, as universal, positions the viewer in the centre of the world. de Certeau refers to the "division of space [which] makes possible a panoptic practice proceeding from a place whence the eye can transform foreign forces into objects that can be observed and measured, and thus control and 'include' them within its scope of vision;" while the elevated vantage point, "[allowed one] to be a solar Eye, looking down like a god."(de Certeau, p. 36 and p. 94) The panoptic perspective was an established motif in surveying discourse. In his Outlines of a System of Surveying, for Geographical and Military Purposes (1827), Sir Thomas Mitchell, as Surveyor-General of New South Wales, wrote that "the consequent necessity [of] clearing summit stations for the theodolites, were great impediments; but I made the most of each station when it had been cleared, by taking an exact panoramic view with the theodolite of the nameless features it commanded." 33

But the panoptic was also a personal - subjective - particular. At Ahuriri in 1852, the surveyor John Rochfort noted: "This is a fine plain, and standing in the centre you see a clear horizon all round, such as you would at sea.". 34 In March 1861, while exploring the grazing prospects of the Mackenzie Plains, John Baker finally reached Lake Pukaki: "Here," Baker confided to his diary, "I obtained my first view of the magnificent Mt. Cook range of the Southern Alps, with Mount Cook itself in the centre dominating over the surrounding snow giants." 35 The panorama was often the reward for physical perseverance; it was the aesthetic satisfaction obtained from an ascent to a panoptic view; the mind satisfied the body as place became picture. "How often have I sat," wrote Samuel Butler of Canterbury in 1872, "on the mountain-side and watched the waving downs, with the two white specks of huts in the distance, and the little square of garden behind them; the paddock with a patch of bright green oats above the huts, and the yards and wool-sheds down on the flat below; all seen as through the wrong end of a telescope, so clear and brilliant was the air, or as upon a colossal model or map spread out beneath me."36

Similarly, the picturesque was a universalising convention, but one constructed from the perspective of personal subjectivity. In the latter years of the eighteenth century, landscape and natural scenery had come to be judged with increasing reference to picturesque standards (Smith, p. 149). In 1794 Uvedale Price defined the picturesque as an aesthetic category, distinct from the sublime and the beautiful, marked by roughess, variation and irregularity; Payne Knight, however, in his Analytical Enquiry into the Principles of Taste (1805), claimed it to be nothing less then "the true visible appearance of things."(Smith, p. 150) Price's definition became the accepted version, and the term was soon expanded to include the exotic, as indigenous flora and fauna were ascribed various picturesque qualities (Smith, p. 150). The link between scientific representation and art had been made by Cook. "The Admiralty," he wrote, "shewed no less attention to science in general, by engaging Mr William Hodges, a Landscape Painter, to embark in this voyage, in order to make drawings and paintings of such places in the countries we should touch at, as might be proper to give a more perfect idea thereof, than could be formed from written description only." 37 Surveyors aimed to provide 'a more perfect idea' of the terrain they encountered, but their pictoral representations were informed by the artistic fashions of the day as much as they were by attempts 
at accuracy. The picturesque, then, universalised the particular: "[the picturesque] allowed not only the contraction of future time but also... the bringing near of distant objects, the magnification of the minute, the God-like survey of the great. The picturesque assembled time and space, presenting society as a community of objects."(Carter, p. 244)

While surveying in Taranaki, the surveyor Edwin Brookes paused to observe a picturesque scene:

Mount Egmont... an enchanting study for an artist, and may be considered as one of the chief sights of Taranaki... Another striking scene is when it is covered low down with snow, the reflection of the sun's rays upon it, mostly toward sunset, change the usual dazzling whiteness to one of the richest tints of light pink, a scene at once so striking that one is chained to the spot as by a magician's wand. This reflection seldom occurs, and even when seen it would be difficult for an artist to imitate either in oil or water-colours, as at best it would be far from the reality... (Brookes, pp. 57-60)

The picturesque was also a personal moment of reflection, a punctuation in the mode of travel. Picturesqueness was a spatial figure of speech which lent itself to description. The picturesque also enabled the eye to explore: "[p]icturesque prospects were one that allowed the eye to wander from object to object: they had their mental counterparts in complex ideas that sparked off trains of thought. Picturesque views might give rise to all kinds of pleasant ideas, but the primary pleasure they gave resided in their picturesqueness itself - in the fact that their structure of casually interlinked and constrasting forms enticed the eye (and the mind) to wander. They were places where the lie of the imagination was made visible."(Carter, pp. 231-240) On commencing a survey of the inland Nelson region, Samuel Stephens wrote "Before leaving I took another hasty view of the lake and adjoining scenery, and also a rough sketch of its now really picturesque character. The view was completely alpine - the back mountain ranges being all completely cased in one continuous sheet of white, the trees and shrubs in the fore ground on the borders of the lake having their boughs incrusted by the snowy mosses and reflecting their graceful images in the still and glassy lake, really formed a most beautiful and striking picture, which was still more enhanced by its novelty, as we had met with no snow since we left England - excepting at a great distance. The scene was rendered still more peculiar, from the intense stillness, and absence of all appearance of animated nature - no sign of waterfowl floating on the lake, or note from the feathered inhabitants of the wood. The sun shining out in full splendour shortly afterwards, added a richness to the wintry picture."(Stephens, Journal, p. 16)

\section{Writing Particulars}

In the writing of landscape, naming and mapping were strategies of the survey that were universalising conventions dependent on particularity. In the European colonisation of New Zealand, naming the land was an attempt to legitimise ownership and the authority of the society that produced those names. The inscription of colonial space is most obvious where 'little Englands' have been replicated on New Zealand soil. The name 'New Plymouth' is a case in point. As if the language itself could impart something of the old world onto the 'new,' British place names were transported wholesale to the colony; for instance, see Stratford, Inglewood, Carlyle, Raleigh, Eltham, Midhurst and Egmont in Taranaki alone. The map of New Zealand also reads like an inventory of British history; Wellington, Auckland, Nelson, Hastings are a few such examples. Indeed, European New Zealanders seem to have defined their environment in terms of legends of arrival, conquest and permanence. For the early European colonists, place names were the most tangible (and perhaps easily transportable) memoir of 'Home' that they could transplant in the colony. In contrast to the colonial society which is created, England and English society simply is. Indeed, as Ross Gibson suggests, "English society... appears to have grown out of the soil rather than planted itself there... East Anglia is not just arable land: it is also Constable country... Cornwall connotes Celtic prehistory... Hampshire evokes maritime myth and history; the Midlands are about industrialization and transport: and so on in a national semiosis that is limitied only littorally." 38

The process of selecting names exhibited a further tension between generic naming and descriptive or particularised nomenclature. As Carter has shown, in Australia "“Cook's names were 
neither meaningless nor arbitrary: they did have a genealogy, but it was a genealogy of particulars, a horizontal disposition to mark things were they occured locally, rather than to organize them hierarchically or thematically."(Carter, p. 8) This stood in contrast to Banks' systematic Linnaean naming, which was based on a epistemology at once universalised and removed from the immediate object (Carter, pp. 20-21). New Zealand place names exhibit a similar tension. In New Zealand, urban topography and street names tended to memorialise founding figures. New Plymouth for instance, has street names which read like the mininutes of a meeting of the New Zealand and Plymouth Companies. Geographical features were largely descriptive or commemorative. On his survey of the lake district of Otago in 1861-2, James McKerrow named Fog Peak, Black Peak, Smooth Peak and Treble Cone on a descriptive basis; the Humboldt Range, Mt Edward, Mt Tyndall and Mt Austed paid homage to eminent European scientists; Mt Walter, Mt Cecil and the Thomson Mountains memorialised local dignatories; while the mountains Ben Nevis, Ben More and Ben Lomond signalled McKerrow's own remembrance of his Scottish home. ${ }^{39}$ The combination of names, drawn both from the metropolitan and local cultures, reflects the ambivalent identity of the colonial, caught between two worlds. 40

In much the same way, mapping the landscape was a universalising strategy of surveying which relied on the production of particulars. "Individual experience becomes meaningful in colonization only where it can be incorporated into a written system of territories." 41 Surveyors participated in cartographic discourse through the medium of the map. "To lay down a useful map," Fitzroy and Raper had considered in the Royal Geographical Journal , "is an easier task than usually supposed, if correct principles be adopted and carefully followed in practice. A field-book... should always be at hand, in which every particular relating to the direction travelled... the distances, times, angles, bearings, and observations, should be noted on the spot and as they occur... ${ }^{42}$ Indeed, mapping determines the way landscape has been conceived; quite literally, the land may be seen as an 'unfolded map.' ${ }^{43}$ Like tables and diagrams maps are also taxonomic ways of ordering categories of contrast and opposition: source vs. variant, center vs. periphery, pure vs. mixed variant, displaying criteria of quality vs. those of quantity. ${ }^{44}$

Surveyors had to operate tactically and with particularity; they had to function with shortterm manoeuvres. They utilised Maori geographical information as and when they required it, and assumed a tactic mobility which enabled them to "accept the chance offerings of the moment, and seize on the wing the possibilities that offer[ed] themselves at any given moment."(de Certeau, p. 37) In doing this, the surveyor entered the space of the Other, and the distribution of power became more tentative and fluid. The implications of this are significant, for it means that the surveyor, as coloniser, was not simply exercising by a one-way distribution of power, but had to constantly negotiate and compromise power relations in transit.

European explorers and surveyors in New Zealand were reliant upon Maori guides for their particular geographical knowledge and their ability to construct 'mental maps,' often transcribed on non-permanent media for the instruction of other Maoris. Between 1769 and 1859 such maps were constructed by Maori for European explorers from Cook, Colenso and Nicholas, through to Mantell, Thomson, Hochstetter and von Haast. Carter has noted how in Australia the European was more often led than he was the leader (Carter, p. 340). Yet for their reliance on native navigation, they often attempted to erase this dependence, or at least their acknowlegement of it, and so tansformed the knowledge of the native guide into a universalized form of knowledge. As Barbara Belyea has commented of European explorers in North America: "the explorers wanted this knowledge not as it came structured in Amerindian ways of seeing and experiencing, but broken down into data which they could fit into their own geographical scheme." 45 Belyea goes on to argue that "the work of cartographic historians repeats in significant ways that of the surveyorexplorers... Although they claim to recognize that Amerindian cartographic conventions are valid and separate, their definition of 'map' remains culture-specific, Eurocentric. The standards by which they judge Amerindian maps are not universal and essential, but - inevitably - conventional and particular (Belyea, p. 275). Alternatively, as Deleuze and Guattari have suggested, this kind of nomandic knowledge is also representative of an alternative kind of power to the centralised imperialist discourses of the West. 46 


\section{Conclusion}

In constructing colonial space and creating a new cultural landscape, colonial surveyors were constantly mediating between particularity and the need to express this detail in a universalized context. It has been suggested here that the task of the surveyor was to negotiate subjective experience and then structure this experience in terms of absolutes, to provide it with productive meaning. In nineteenth-century New Zealand, the act of surveying - as a discourse of settlement and dispossession, of reading and writing landscape - was the product of this tension. As a discourse ostensibly predicated on universals, colonial surveying was as much dependent on particularity; indeed, as Emerson once remarked, "the Universal does not attract us until housed as an individual."

1 Edwin Stanley Brookes, Frontier Life: Taranaki, New Zealand (Auckland, 1892), p. 5.

2 Mary Louise Pratt, "Scratches on the Face of the Country: or, What Mr Barrow Saw in the Land of the Bushmen," in

"Race," Writing and Difference, ed. Henry Louis Gates Jnr. (Chicago: University of Chicago Press, 1986), p.125.

3 Robert Sack, Human Territoriality its Theory and History (Cambridge, 1986), p. 87.

4 Paul Carter, The Road to Botany Bay: An Essay in Spatial History (London: Faber 1987), p.128.

5 Brad Patterson, Reading Between the Lines, Ph.D. Thesis, Department of Geography (Victoria University: Wellington, 1984), pp. 4-5.

6 Sneja Gunew, "Postmodern Tensions: Reading for (Multi)Cultural Difference," Meanjin 49, 1 (1990): 22.

7 J. K. Noyes, Colonial Space: Spatiality in the Discourse of German South West Africa 1884-1914 (Chur, Switzerland: Harwood, 1992), p. 285. It can be argued that not to attend to the deconstruction of colonial discourses is to accord them the legitimacy sought in their initial production.

8 Robert Young, White Mythologies: Writing History and the West (New York, 1990), p.145.

9 Bernard Smith, Imagining the Pacific In the Wake of the Cook Voyages (New Haven: Yale University Press: 1992), p. ix.

10 Theodor W. Adorno, Negative Dialectics, trans. E. B. Ashton (London: Routledge, 1973), p.173.

11 A. V. Miller, Hegel's Philosophy of Nature (Oxford, 1970), pp. 28-29.

12 Jacques Derrida, Of Grammatology (Baltimore: The Johns Hopkins University Press, 1976).

13 Elizabeth Gross, "Derrida, Irigaray, and Deconstruction," Left-Right, Intervention, 20 (1986): 73. See Jonathan Culler, On

Deconstruction: Theory and Criticism after Structuralism (Ithaca: Cornell University Press, 1982); and John M. Ellis, Against Deconstruction (Princeton: Princeton University Press, 1989).

14 Lucien Goldmann, Cultural Creation in Modern Society, trans. Bart Grahl (St. Louis: Telos, 1976), p.112. For further discussion see Norman Simms, The Humming Tree: A Study in the History of Mentalities (Chicago: University of Illinois Press, 1992), pp..59-87.

15 Michel de Certeau, The Practice of Everyday Life, trans. Steven Rendall (Berkeley: University of California Press, 1984), p.117.

16 Michel Foucault, "Space, Knowledge and Power," The Foucault Reader, ed. Paul Rabinow (New York: Pantheon, 1984), p. .252. See also Michel Foucault, "Questions of Geography," Power/Knowledge: Selected Interviews and Other Writings 1972-1977, ed. and trans. Colin Gordon (Brighton: Harvester, 1980); Foucault, 'Of Other Spaces', Diacritics 16 (1986).

17 Gilles Deleuze and Felix Guattari, Anti-Oedipus: Capitalism and Schizophrenia, trans. Robert Hurley, Mark Seem and Helen R. Land (New York: Viking, 1975), p. 287.

18 See John Pascoe (ed.), The Great Journey: An Expedition to Explore the Interior of the Middle Island, New Zealand, 1846-8 (Christchurch, 1952); see also Thomas Brunner, Journal of the Royal Geographical Society (1850), Vol XX: 344-378: Samuel Stephens, Journal, MS Papers 2698-1A, Alexander Turnbull Library.

19 Homi K. Bhabha, "Signs Taken as Wonders: Questions of Ambivalence and Authority under a Tree outside Delhi, May 1817," in "Race," Writing and Difference, ed. Henry Louis Gates Jnr. (Chicago: University of Chicago Press, 1986$),$ p. 176.

${ }^{20}$ Homi K. Bhabha, "Of Mimicry and Man: The Ambivalence of Colonial Discourse', October 28, Spring 1984: 125-131.

21 Resident Agent, New Plymouth to Colonel Wakefield, 31 July 1843, cited in B. Wells, The History of Taranaki (New Plymouth, 1878), p. 97.

22 J. Rutherford, Sir George Grey K. C. B., 1812-1898: A Study in Colonial Government (London, 1961), p. 449 and 551.

23 W. H. Skinner,"Diary, "MS020/1, Taranaki Museum. See also Skinner's comments on "Native Unrest in Central Taranaki" in Reminisences of a Taranaki Surveyor (New Plymouth, 1946), pp. 48-49.

24 S. P. Smith, Reminiscences, TS, Auckland Institute and Museum, p. 42.

25 Taussig further suggests that "mimesis as fact and epistemic moment can be understood as redolent with the trace of that space between, a colonial space par excellence, a windswept Fuegian space where mankind bottoms out into fairy-tale metamorphoses with children and animals, so mimesis becomes an enactment not merely of an original but by an 'original'." Michael Taussig, Mimesis and Alterity: A Particular History of the Senses (New York: Routledge, 1993), p. 78-9. See also Norman Simms, Points of Contact: A Study of the Interplay and Intersection of Traditional and Non-Traditional Literatures, Cultures, and Mentalities (New York, 1991).

26 Edward W. Said, Orientalism (London: Routledge, 1978), p.32.

27 John Pascoe (ed.), The Great Journey and Thomas Brunner, Journal of the Royal Geographical Society vol. XX(1850): $344-378$.

28 Bernard Smith, European Vision and the South Pacific, 2nd ed. (Sydney: Harper and Row, 1985).

29 Felton Mathew, NZ Mss 78-79, Papers 1846-48, Auckland Public Library.

30 F. A. Carrington to the Secretary of the New Zealand Company, 22 September 1841, MS00/1 A96, Taranaki Museum.

31 Charles Douglas, Diary, MS Papers 0090:1, ATL, ts, p.4.

32 For further discussion of Carter's argument see Andrew Hassam, "'As I Write': Narrative Occasions and the Quest for Self-Presence in the Travel Diary," ARIEL: A Review of International English Literature, 21, 4, October 1990: 33-47. 
33 Sir Thomas L. Mitchell, Three Expeditions into the Interior of Eastern Australia, (London, 1838-39) II, pp. .318-19, cited in Smith, European Vision, p. 214.

34 John Rochfort, Adventures of a Surveyor in New Zealand (London, 1853), p. 30.

35 J. H. Baker, Diary 1857-97, 5 vols, Ms, ATL.

36 Samuel Butler, Erewhon; or, Over the Range (Golden Press: Auckland, 1973), p. 20.

37 J. Cook, A Voyage towards the South Pole, and Round the World (London, 1777) 2 vols, i, p.xxxiii, cited in Smith, European Vision, p.43.

38 Ross Gibson, South of the West: Postcolonisalism and the Narrative Construction of Australia (Bloomington, Indiana, 1992), p. 65-66.

39 The streets Vivian, St Aubyn, Hine, Buller, Devon, Leach, Lemon, Pendarves, Gilbert, Eliot and Cutfield Road memorialise the Directors of the Plymouth Company; Young Street, Currie Street, Wakefield Street, Fillis Street, Molesworth Street, Courtnay Street and Woollcombe Terrace the Directors of the New Zealand Company; Queen, Bell and Hobson streets honour public figures; Standish, Barrett and King streets salute those of local repute; and Liardet Street, Octavius Place and, of course, Carrington Road, the surveyors. Murray Moorhead, Tales of Old North Taranaki (New Plymouth, 1991).

40 Sir Thomas MacKenzie, MS Papers 3922-1, ATL.

41 See Bhabha, "Of Mimicry and Man: The Ambivalence of Colonial Discourse," pp. 125-131.

42 Noyes, Colonial Space, p. 87. Or, as Deleuze and Guattari have suggested, as soon as [individual experience] is inserted into a system of writing, any unmediated visibility of the world is subsumed in a 'kind of blindness.' Deleuze and Guattari, Anti-Oedipus, p. 205.

43 H. Raper and R. Fitzroy, Royal Geographical Journal, vol 24.

44 Elizabeth Ferrier, "Mapping Power and Contemporary Cultural Theory," antithesis, 4,1, (1990): 41.

45 Johannes Fabian, Time and the Other: How Anthropology Makes its Object (New York: Columbia University Press, 1983), p. 55.

46 See P. L. Barton, "Maori Geographical Knowledge and Mapping: A Synopsis," Turnbull Library Record, 13, 1, May 1980: 5-25.

47 Barbara Belyea, 'Amerindian Maps: The Explorer as Translator', Journal of Historical Geography, 18, 3 (1992): $267-277$.

48 Gilles Deleuze and Felix Guattari, Nomadology The War Machine, trans. Brian Massumi (New York: Semiotext(e), 1986). 